\title{
Advanced optical technologies for monitoring estuaries and coastal environments
}

\section{Tecnologías ópticas avanzadas para monitorear estuarios y ambientes costeros}

\author{
D. Pereira ${ }^{1 *}$, O. Frazão ${ }^{1}$, J. Ferreira ${ }^{1}$, I. Dias ${ }^{1}$, J.M. Dias ${ }^{2}$ \\ M. Teixeira ${ }^{4}$, N. Vaz ${ }^{2}$, A. Quintela ${ }^{4}$ J.F. Lopes ${ }^{2}$ \\ J.L. Santos ${ }^{1,3}$ \\ ${ }^{1}$ INESC Porto \\ UOSE, Rua do Campo Alegre 687 \\ 4169-007 Porto, Portugal \\ * E-mail: dap@goe.fc.up.pt \\ ${ }^{2}$ CESAM \\ Departamento de Física \\ Universidade de Aveiro \\ 3810-193 Aveiro, Portugal \\ ${ }^{3}$ Faculdade de Ciências da Universidade do Porto \\ Rua do Campo Alegre 687 \\ 4169-007 Porto, Portugal \\ ${ }^{4}$ CABELTE S.A. \\ Apartado 3 \\ 4412 Praia da Granja \\ Valadares Codex, Portugal
}

Recibido en junio de 2003; aceptado en abril de 2004

\begin{abstract}
In recent years the need to monitor different parameters has led to the development of several architectures able to make real time, un-attended measurements. Particularly in regard to environmental issues, it is very important that the equipment and measuring systems be small and light to avoid maximum interference of the ecosystems studied. In this context, optical fibre sensors have become extremely attractive for use in natural environments to monitor different parameters of biological interest, due to their intrinsic small weight and size and low reactivity to chemical and biological parameters. In this paper we present an innovative and technologically advanced system for the simultaneous measurement of temperature and salinity based on optical fibre Bragg grating sensors and on an optical sensing cable especially designed for large-scale and distributed or quasi-distributed measurements. A prototype of this optical cable was installed in the Mira Channel at Ria de Aveiro, Portugal. Temperature variation during three weeks from 4 to 23 June 2002 is investigated and presented here.
\end{abstract}

Key words: Fiber Bragg graing, wavelength, temperature, salinity, monitoring.

\section{Resumen}

En años recientes la necesidad de monitorear diferentes parámetros condujo al desarrollo de diversas arquitecturas capaces de hacer mediciones en tiempo real, de manera automatizada. Particularmente cuando se trata de parámetros ambientales es muy importante que equipos y sistemas de medición sean pequeños y ligeros para evitar al máximo la interferencia con los ecosistemas estudiados. En este contexto, los sensores de fibra óptica han resultado muy atractivos para monitorear diferentes parámetros de interés biológico en ambientes naturales gracias a sus reducidos peso y tamaño, y a su baja reactividad hacia parámetros químicos y biológicos. En este artículo se presenta un sistema innovador y tecnológicamente avanzado para la medición simultánea de temperatura y salinidad, basado en sensores de fibra óptica con rejillas de Bragg y un cable de fibra óptica especialmente diseñado para mediciones a gran escala y distribuidas o quasi-distribuidas. En este trabajo se presentan los resultados obtenidos de investigar la variabilidad térmica mediante un prototipo de este cable óptico que fue instalado en el Canal de Mira de la Ría de Aveiro (Portugal) durante tres semanas entre el 4 y el 23 de junio de 2002.

Palabras clave: Rejillas de Bragg, longitud de onda, temperatura, salinidad, seguimiento. 


\section{Introduction}

It is nowadays recognized that coastal and estuarine environments are privileged zones for bio-diversity evolution. By their own nature they are extremely sensitive to changes in the boundary conditions, particularly in regards to water properties. In this sense, emphasis should be placed on the diagnosis and surveillance of the most fragile and mutable environments that are often subjected to considerable stress due to an excess of human activities.

Coastal and estuarine ecosystems have special characteristics, since they are areas where the salt water carried by the ocean tides converges with fresh water input by rivers. The temporal variation of these water flows, together with the geometric characteristics of the area and different meteorological conditions, determine the equilibrium mixture between salt and fresh water. The temperature and salinity gradients established, as well as the salt- and fresh-water flows, have a decisive influence on the water circulation and on the evolution of different vegetal and animal species in these coastal habitats, providing some of the most varied and unstable environments on Earth.

Ría de Aveiro (Portugal) is an example of this kind of zone. It is a shallow lagoon with a very complex geometry, connected to the Atlantic Ocean through a single artificial channel. Most of its water exchange with the ocean takes place by tidal input/output across this narrow entrance. The input of fresh water occurs through several small rivers by different channels discharging on the lagoon. The most important river, the Vouga River, is responsible for approximately 2/3 of the fresh-water input to the lagoon. These characteristics make Ría de Aveiro an ideal place to implement and test innovative sensing systems for monitoring estuaries, lagoons and coastal zones.

The use of optical fibre sensors in the marine environment has, so far, been limited; however, they offer many potential advantages, such as low attenuation, allowing remote location of the electro-optical power supply and control units from the measuring area; capability to perform distributed measurements over many kilometres; small physical size and non-intrusive nature, even when in armoured form; high speed of response; and excellent salt-water corrosion resistance of optical fibres.

In this paper we present two new technologies for monitoring estuaries, lagoons and coastal zones. One is an optical head sensor for the simultaneous measurement of temperature and salinity, and the other is an optical sensing cable to monitor temperature. The main advantage of these two technologies is the possibility of integrating both in a system for real-time monitoring these environmentally relevant measurements. Other advantages arise from the low costs involved in implementing and maintaining this technology. Conventional technology, which requires electrical transducers especially designed to measure variations in the electrical conductivity of water, is hard to install, has a short durability and, most importantly, is not immune to electromagnetic interference, which in some cases is responsible for troubleshooting in measurements.

\section{Introducción}

Hoy en día es bien sabido que los ambientes costeros y estuarinos son zonas privilegiadas para la evolución de la biodiversidad. Por su naturaleza, estos ambientes son extremadamente sensibles a cambios en las condiciones de frontera, en particular con respecto a las propiedades del agua. En este sentido, se debería de poner énfasis en el diagnóstico y vigilancia de los ambientes más frágiles y alterables que con frecuencia están sometidos a estrés debido actividades humanas en exceso.

Los ecosistemas costeros y estuarinos tienen características especiales, ya que son áreas donde convergen agua de mar por la propagación de la marea y agua dulce aportada por los ríos. La variación temporal de estos flujos de agua, junto con las características geométricas de la zona y diferentes condiciones meteorológicas, determinan la mezcla de equilibrio entre agua dulce y marina. Los gradientes de temperatura y salinidad establecidos, así como los flujos de agua dulce y agua de mar tienen una influencia decisiva sobre la circulación del agua y sobre la evolución de diversas especies de animales y plantas en estos hábitats costeros que proporcionan algunos de los ambientes más variados e inestables de la Tierra.

La Ría de Aveiro (Portugal) es un ejemplo de este tipo de zona. Es una laguna somera con una geometría muy compleja, que se conecta con el Océano Atlántico mediante un canal artificial. Su mayor intercambio de agua se realiza por el flujo y reflujo de la marea a través de esta angosta entrada. Recibe agua dulce de varios ríos que descargan hacia la laguna por diferentes canales. El río más importante es el Vouga, que aporta 2/3 del agua dulce de la laguna. Estas características hacen que la Ría de Aveiro sea un lugar ideal para implementar y probar sistemas novedosos de detección para monitorear estuarios, lagunas y zonas costeras.

El uso de sensores de fibra óptica en el ambiente marino ha sido, hasta ahora, limitado; sin embargo, éstos ofrecen muchas ventajas potenciales, como una baja atenuación que permite colocar las unidades de suministro de energía electro-óptica y de control lejos del área a monitorear; la capacidad de realizar mediciones distribuidas a lo largo de varios kilómetros; un tamaño físico reducido y no intrusivo, aun teniendo un armado significativo; alta velocidad de respuesta; y gran resistencia al ataque corrosivo del agua de mar a las fibras ópticas.

En este trabajo se presentan dos nuevas tecnologías para el monitoreo de estuarios, lagunas y zonas costeras. Una es un sensor óptico para la medición simultánea de temperature y salinidad, y la otra es un cable de fibra óptica para monitorear la temperatura. La principal ventaja de estas dos tecnologías es la posibilidad de integrar ambas en un sistema dedicado a monitorear en tiempo real estos parámetros de relevancia ambiental. Otra ventaja son los bajos costos involucrados en la implementación y el mantenimiento de esta tecnología. La tecnología convencional, que utiliza transductores eléctricos especialmente diseñados para medir las variaciones en la conductividad eléctrica de agua, es difícil de instalar, dura poco tiempo y principalmente, no está excenta de interferencia 
In this context it should be mentioned that in several cases some sensitive measurements performed by electrical transducers can be affected by electromagnetic interference or noise. This happens most often in gauge systems as well as in LVDTs (linear variable differential transformers) when the external electrical supply has slight fluctuations in tension. Furthermore, when placed in field environments under severe weather conditions like thunders, erroneous measurements due to electrical discharges and humidity can occur. In this particular case, electromagnetic interference can be due to the own nature of the installation which demands an individual cable for each immersed sensor. These are then collected in the proximity to the observation station and, as a result, cross electromagnetic signal effects could occur.

It should also be mentioned that the electrical conductivity of water is an indicator not only of the degree of salinity (ionic presence) but, in addition, it may be used to determine the water flow in a dynamic system. In fact, the conductivity is a measurement of the amount of electrical charges, that if being adverted by a water current field, and subjected to the Earth magnetic field, will induce an electrical potential difference proportional to the water flow. Measurement techniques based on motion-induced electric fields (MIV) have increased the interest of oceanographers in studies of ocean flow to provide detailed information about the velocity structure of ocean currents.

\section{Fibre Bragg grating theory}

Optical fibre is a glass element that comprises two concentrical cylinders with a slightly different refractive index covered by a polymeric material that ensures mechanical protection and resistance. The inner cylinder is the core and the outer the cladding. The effective refractive index is a characteristic parameter of the glass material and is associated with the propagation speed of light inside it; the difference between the refractive indexes of the materials in the optical fibre is responsible for its waveguide capacity.

In addition to the high potential for developing optical fibre communications, investigations of the photosensitivity mechanisms in optical fibres allow the construction of a new type of sensors: optical fibre sensors.

A fibre Bragg grating (FBG) is a periodic modulation of the refractive index of the core of a single mode optical fibre, written by exposure to UV light in the region around $248 \mathrm{~nm}$. This fabrication process is based on the photosensitive mechanism, which is observed in Ge-doped optical fibres. If broadband light is travelling through an optical fibre containing such a periodic structure, its diffractive properties promote that a very narrow wavelength band is reflected back. The centre wavelength of this band can be represented by the well known Bragg condition: $\lambda_{B}=2 n_{\text {eff }} \Lambda$, where $\lambda_{B}$ is the centre wavelength, $n_{\text {eff }}$ is the effective index of the guided mode and $\Lambda$ is the period of the refractive-index modulation. The FBG resonance wavelength will vary according to the changes in electromagnética, la cual en algunos casos es responsable de importantes errores en las mediciones.

En este contexto, cabe mencionar que en muchos casos algunas mediciones de sensibilidad obtenidas con transductores eléctricos pueden verse afectadas por interferencia electromagnética ruido. Esto ocurre con más frecuencia en sistemas de calibración, así como en transformadores diferenciales de variación lineal (LVDTs) cuando el suministro electrico externo tiene ligeras fluctuaciones de tensión. Además, cuando éstos se encuentran en el campo, bajo condiciones climáticas extremas tales como tormentas eléctricas, pueden ocurrir mediciones erróneas debidas a descargas eléctricas o humedad. En este caso particular, la interferencia electromagnética pudo deberse a la propia naturaleza de la instalación, la cual requiere un cable individual para cada sensor sumergido. Estos estos son recobrados posteriormente cerca de las estaciones de observación y, como resultado de ello, se puede generar un entrecruzamiento de señales electromagnéticas.

También debe mencionarse que la conductividad eléctrica del agua no sólo es un indicador de su grado de salinidad (presencia iónica) sino que, además, puede ser utilizada para determinar el flujo de agua en un sistema dinámico. De hecho, la conductividad es una medida de la cantidad de cargas eléctricas que, al ser advertidas en un campo de corrientes de agua, y sujetas al campo magnético de la Tierra, inducirán una diferencia de potecial eléctrico porporcional al flujo de agua. Las técnicas de medición basadas en campos eléctricos inducidos por movimiento (MIV) han incrementado el interés de los oceanógrafos en los estudios de flujos en el océano para proveer información detallada acerca de la estructura de la velocidad de las corrientes oceánicas.

\section{Teoría de las rejillas de Bragg en fibras ópticas}

La fibra óptica es un elemento de vidrio que comprende dos cilíndros concéntricos con un índice de refracción ligeramente diferente, recubiertos por un material polimérico que les brinda protección mecánica y resistencia. El cilindro interior es el núcleo y el exterior es el revestimiento. El índice de refracción efectivo es un parámetro característico del material vitreo y está asociado con la velocidad a la que se propaga la luz dentro de él; la diferencia entre los índices de refracción de los materiales de la fibra óptica es la que determina su capacidad de guía de ondas.

Además del gran potencial de desarrollo de las comunicaciones con fibra óptica, el estudio de los mecanismos de la fotosensibilidad en las fibras ópticas permite crear un nuevo tipo de sensores, los sensores de fibra óptica.

Una rejilla de Bragg en una fibra óptica (FBG, por sus siglas en inglés) es una modulación periódica del índice de refracción del núcleo de una fibra óptica monomodo, dibujada por medio de exposición a luz UV en la región alrededor de $248 \mathrm{~nm}$. Este proceso de fabricación se basa en un mecanismo fotosensible que se observa en fibras ópticas dopadas con Ge. 
temperature or refractive index experienced by the fibre. For a silica fibre the wavelength-temperature sensitivity is $\sim 13 \mathrm{pm}^{\circ} \mathrm{C}^{-1}$ for a Bragg wavelength centred at $1555 \mathrm{~nm}$.

Temperature and index variations applied to the gratings cause shift in the Bragg wavelengths as

$$
\Delta \lambda_{B}=K_{T} \Delta T+K_{n} \Delta n
$$

The thermal sensitivity, $K_{T}$, depends on the thermal expansion of the fibre and, essentially, on the thermo-optic coefficient. On the other hand, the index sensitivity, $K_{n}$, depends on the relative diameters between the core and the cladding. In this way, equation (1) can be used to discriminate between the effects of the changes in temperature and refractive index applied to the sensor head:

$$
\left[\begin{array}{l}
\Delta T \\
\Delta n
\end{array}\right]=\frac{1}{\Delta}\left[\begin{array}{cc}
K_{n 2} & -\Delta \lambda_{B 1} \\
-K_{T 2} & K_{T 1}
\end{array}\right]\left[\begin{array}{l}
\Delta \lambda_{B 1} \\
\Delta \lambda_{B 2}
\end{array}\right]
$$

where $\Delta=K_{T 1} K_{n 2}-K_{n 1} K_{T 2}$.

\section{Temperature and salinity sensor}

In this work, refractive index measurements are achieved by etching the fibre cladding in the region of the grating to a diameter such that the evanescent field of the mode interacts with the immediate surrounding environment. With this configuration, the value of the effective refractive index of the waveguide mode is directly affected by the refractive index of the medium where the fibre is immersed.

To different concentrations of salt correspond different surrounding refractive indexes, which can be measured. The reduction of the cladding diameter is made by chemical attack with an aqueous solution of fluoridic acid (HF 40\%).

Considering the Bragg relation mentioned above, this means that associated with the etching process there is a variation of the Bragg wavelength of the FBG given by

$$
\partial \lambda_{B}=2 \Lambda \partial n_{e f f}
$$

Therefore, in such a stage the variation of the Bragg wavelength of the FBG is only related to the variation of the refractive index of the surrounding medium (Asseh et al., 1998). This constitutes the principle of the salinity sensor proposed in this work.

The relation between the refractive index and the corresponding salt concentration is shown in figure 1 (Quan et al., 1995). The values were measured with an Abbe refractometer. Figure 2 shows the evolution of the refractive index with temperature. From these two graphs it is easy to see that the influence of temperature on the refractive index, and consequently on the sensor response, is one order of magnitude less
Si por una fibra óptica que contiene una estructura periódica de este tipo viaja luz de banda ancha, sus propiedades de difracción promueven que se refleje en respuesta una longitud de onda muy angosta. La longitud de onda central, de esta banda, puede representarse por la bien conocida condición de Bragg: $\lambda_{\mathrm{B}}=2 n_{\text {eff }} \Lambda$, donde $\lambda_{\mathrm{B}}$ es la longitud de onda central, $n_{\mathrm{eff}}$ es el índice efectivo del modo de guía y $\Lambda$ es el periodo de modulación del índice de refracción. La longitud de onda de resonancia de FBG variará de acuerdo a los cambios de temperatura o del índice de refracción de la fibra. Para una fibra de sílice, la sensibilidad longitud de onda-temperatura es $\sim 13$ $\mathrm{pm}^{\circ} \mathrm{C}^{-1}$ para una longitud de onda de Bragg centrada en los $1555 \mathrm{~nm}$.

Los cambios de temperatura y de índice de refracción en las rejillas causan un cambio en las longitudes de onda de Bragg dado por

$$
\Delta \lambda_{B}=K_{T} \Delta T+K_{n} \Delta n
$$

La sensibilidad térmica, $K_{T}$, depende de la expansión térmica de la fibra $\mathrm{y}$, esencialmente, del coeficiente termoóptico. Por otro lado, la sensibilidad del índice, $K_{n}$, depende de los diámetros relativos entre el núcleo y el revestimiento. Por tanto, la ecuación (1) puede ser usada para discriminar entre los efectos causados por los cambios de temperatura y los del índice experimentados por la cabeza del sensor:

$$
\left[\begin{array}{l}
\Delta T \\
\Delta n
\end{array}\right]=\frac{1}{\Delta}\left[\begin{array}{cc}
K_{n 2} & -\Delta \lambda_{B 1} \\
-K_{T 2} & K_{T 1}
\end{array}\right]\left[\begin{array}{l}
\Delta \lambda_{B 1} \\
\Delta \lambda_{B 2}
\end{array}\right]
$$

donde $\Delta=K_{T 1} K_{n 2}-K_{n 1} K_{T 2}$.

\section{Sensor de temperatura y salinidad}

En este trabajo, las mediciones del índice de refracción se logran mediante el ataque químico de la fibra de revestimiento en la región de la rejilla hasta un diámetro tal que el campo evanescente del modo interactúa con el ambiente circundante. Con esta configuración, el valor del índice de refracción efectivo del modo de guía de ondas es directamente afectado por el índice de refracción del medio en donde la fibra está immersa.

A diferentes concentraciones de sal corresponden diferentes índices de refracción circundantes, los cuales se pueden medir. La reducción del diámetro del revestimiento se realiza mediante ataque químico con una solución acuosa de ácido fluorhídrico (HF 40\%).

Considerando la relación de Bragg ya mencionada, esto significa que asociada con el proceso de ataque químico existe una variación de la longitud de onda de Bragg de la FBG dada por

$$
\partial \lambda_{B}=2 \Lambda \partial n_{e f f}
$$




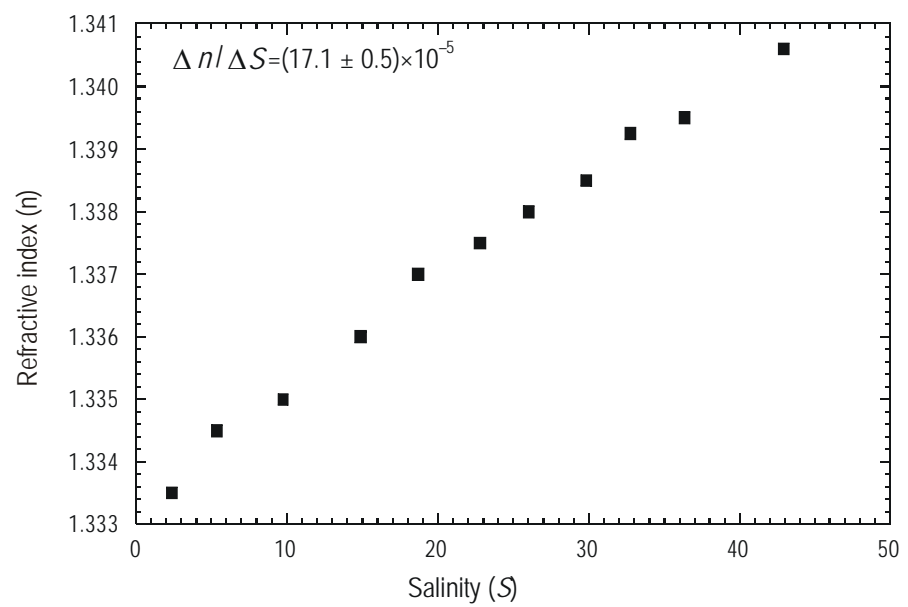

Figure 1. Relation between refractive index and salinity.

Figura 1. Relación entre el índice de refracción y la salinidad.

than that produced by a direct index change at room temperature. Hence, in a first approximation, it is possible to ignore the influence of temperature on the refraction index. The peak power and wavelength variations during the chemical attack are presented in figures 3 and 4 , respectively. The abrupt zone observed indicated that the core boundary of the fibre is almost exposed to air, which alters the guided wave conditions and consequently the wavelength FBG response. The abrupt zone in the peak power graph indicates a faster degradation of the sensor in the neighbourhood of the core.

The temperature calibrations of both sensors are presented in figure 5. As expected, both sensors have the same behaviour regarding temperature. The response of both sensors to refractive index changes in a relatively large range and the response to refraction index changes of the salinity sensor in the range corresponding to the salt concentrations in nature are shown in figures 6 and 7, respectively. The main aspect that arises from these results is the linearity of the results, making them attractive for environmental monitoring (Esteban et al., 1999).

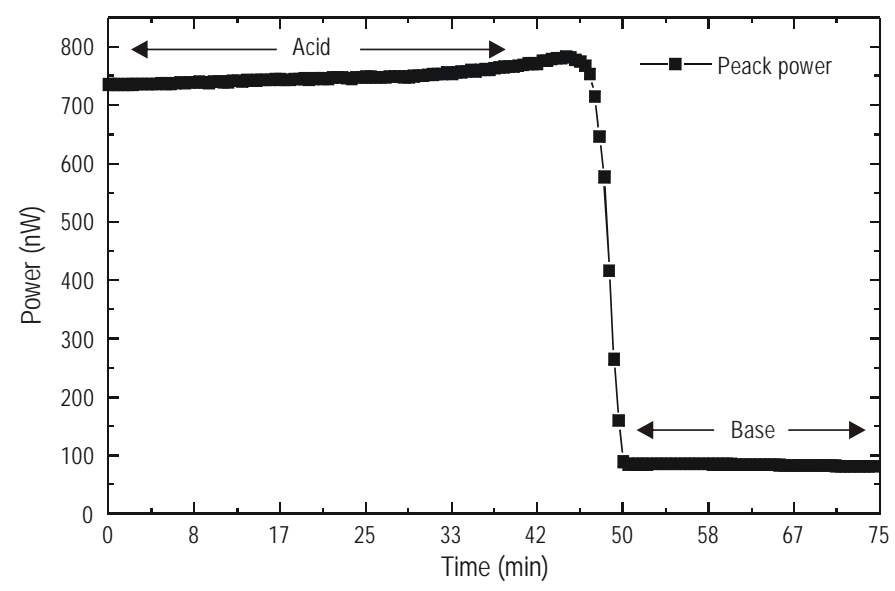

Figure 3. Peak power variation during the chemical attack.

Figura 3. Variación de la potencia máxima durante el ataque químico.

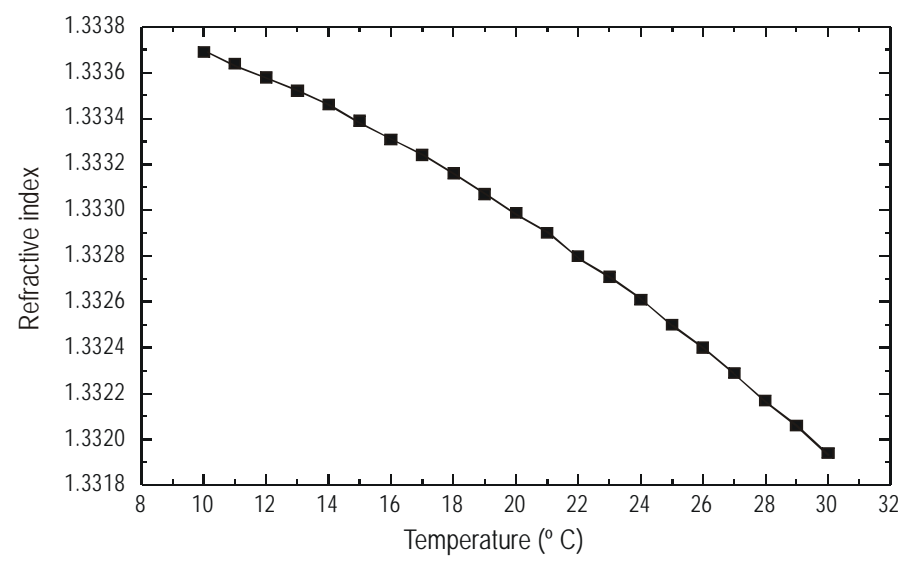

Figure 2. Relation between refractive index and temperature. Figura 2. Relación entre el índice de refracción y la temperatura.

Por tanto, en este caso la variación de la longitud de onda de Bragg de la FBG está relacionada sólo con la variación del índice de refracción del medio circundante (Asseh et al., 1998). Esto constituye el principio del sensor de salinidad propuesto en este trabajo.

En la figura 1 se muestra la relación entre el índice de refracción y la concentración de sal correspondiente (Quan et al., 1995). Los valores fueron medidos con un refractómetro Abbe. La figura 2 presenta la evolución del índice de refracción con la temperatura. Estas dos gráficas muestran claramente que la influencia de la temperatura sobre el índice de refracción, y consecuentemente sobre la respuesta del sensor, es un orden de magnitud menor que la producida por un cambio directo en el índice a temperatura ambiente. Por tanto, en una primera aproximación, es posible ignorar la influencia de la temperatura sobre el índice de refracción. En las figuras 3 y 4 se presentan las variaciones de la potencia máxima y de la longitud de onda, respectivamente, durante el ataque químico. La zona abrupta que se observa indica que la frontera del núcleo de la fibra está casi expuesta al aire, lo que altera las condiciones de la onda dirigida y consecuentemente la respuesta de la longitud de onda de la FBG. La zona abrupta en la gráfica de la potencia máxima indica una degradación más rápida del sensor alrededor del núcleo.

Las calibraciones de temperatura de ambos sensores se presentan an la figura 5. Como es de esperar, ambos sensores tienen el mismo comportamiento con relación a la temperatura. La respuesta de ambos sensores a los cambios del índice de refracción en un intervalo relativamente grande y la respuesta a los cambios del índice de refracción del sensor de salinidad en el intervalo correspondiente a las concentraciones salinas naturales se muestran en las figuras 6 y 7 , respectivamente. El principal aspecto que surge de estos resultados es su linealidad, lo que los hace atractivos para el monitoreo ambiental (Esteban et al., 1999).

En la figura 8 se muestra el arreglo experimental utilizado en el laboratorio para probar el sensor de salinidad. La luz emitida por una fuente de banda ancha (BBS) es dirigida hacia los 


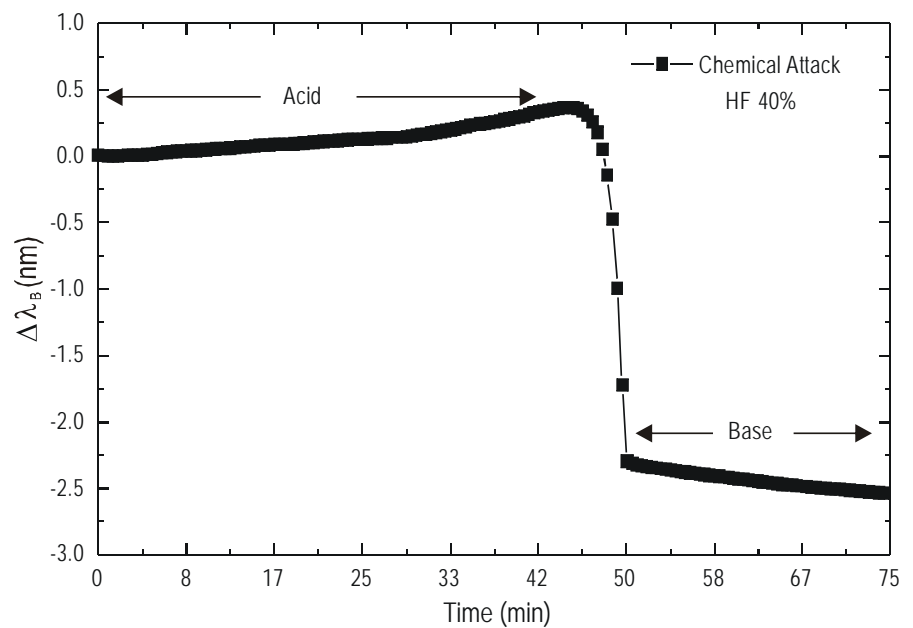

Figure 4. Wavelength variations during the chemical attack.

Figura 4. Variaciones de la longitud de onda durante el ataque químico.

Figure 8 shows the setup used in the laboratory to test the salinity sensor. The light emitted from a broadband source (BBS) is directed toward the sensors. The light reflected from each sensor corresponding to the Bragg wavelength is then analyzed by an optical spectrum analyzer (OSA) controlled by an acquisition program done in LabViewTM for this particular purpose. Once some temperature or salinity fluctuation occurs, the shift induced in the Bragg wavelengths is observed following the principles outlined above.

\section{Optical cable sensing}

Here we present an environmental monitoring system that was designed and implemented for the PROTEU project (PROTEU: Advanced technologies for monitoring estuaries and coastal environments, FCT-PDCTM/P/MAR/15275/1999) and that is currently under field tests. At present, only water temperature in the Mira Channel of Ría de Aveiro (see fig. 9)

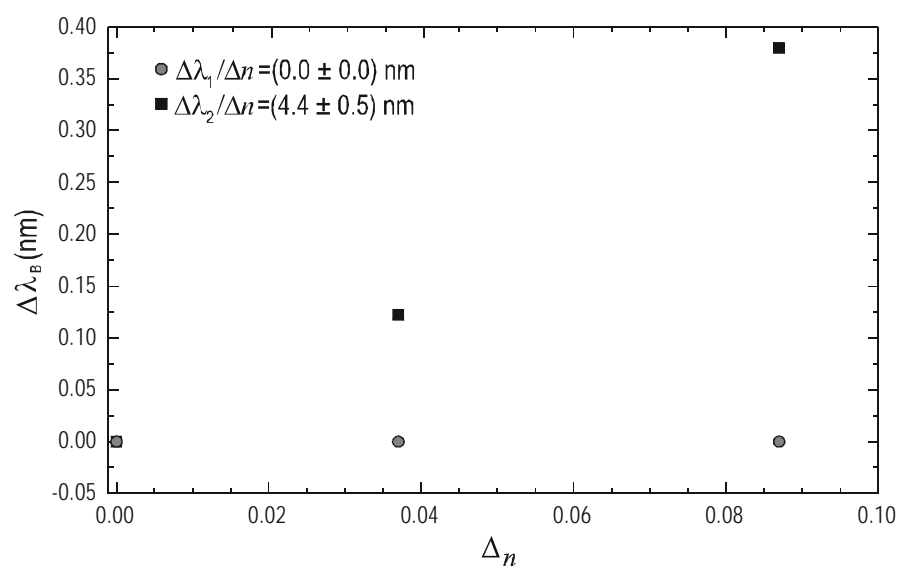

Figure 6. Refractive index response of both sensors.

Figura 6. Respuesta de ambos sensores al índice de refracción.

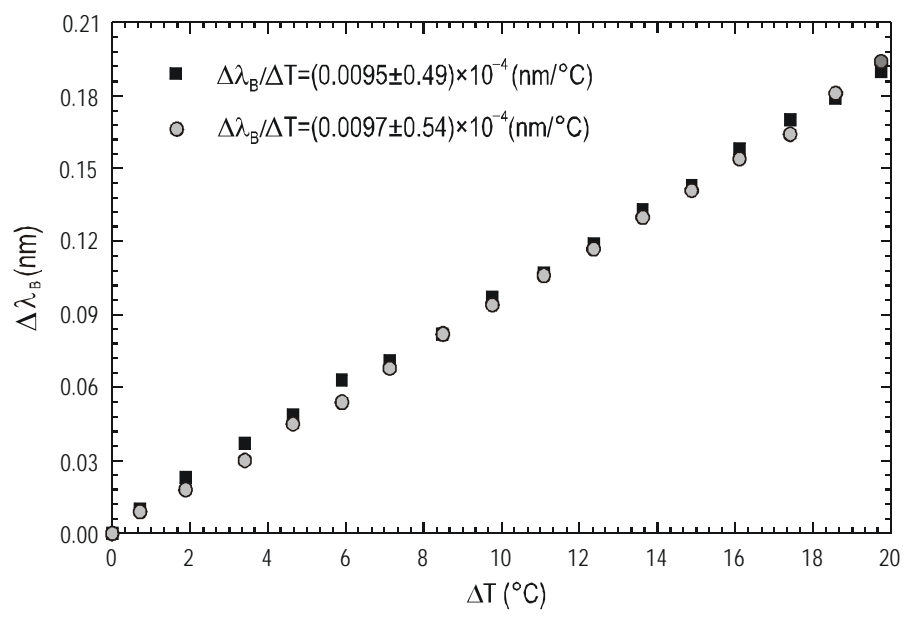

Figure 5. Temperature response of both fibre Bragg grating sensors. Figura 5. Respuesta de ambos sensores de fibra óptica con rejillas de Bragg a la temperatura.

sensores. Posteriormente se analiza la luz reflejada por cada sensor correspondiendo a la longitud de onda de Bragg mediante un analizador de espectro óptico controlado por un programa de adquisición hecho ex profeso en LabViewTM. Una vez ocurrida alguna fluctuación de temperatura o salinidad, se observa cómo el cambio inducido en las longitudes de onda de Bragg sigue los principios mencionados arriba.

\section{Detección por cable de fibra óptica}

Aquí hemos presentado un sistema de monitoreo ambiental diseñado e implementado como parte del proyecto PROTEU (PROTEU: Tecnologías avanzadas para monitorear estuarios y ambientes costeros, FCT-PDCTM/P/MAR/15275/1999), y que actualmente se está poniendo a prueba en el campo. Por lo pronto solamente se ha medido la temperatura del agua en al Canal de Mira de la Ría de Aveiro (ver fig. 9), pero próximamente también se llevarán a cabo mediciones con el sensor de

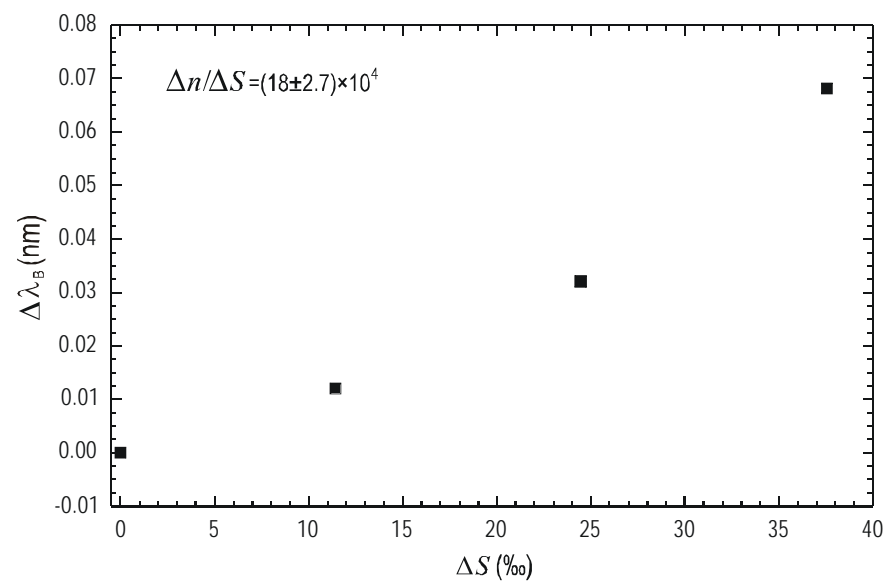

Figure 7. Salinity response of the sensor. Figura 7. Respuesta del sensor a la salinidad. 
has been measured, but in the near future the salinity sensor (previously mentioned) will also record measurements in the extremity of the optical cable. Monitoring is made by a specially designed optical fibre cable (TON GERE), with Bragg grating sensors, manufactured by CABELTE S.A.

The optical cable comprises three optical fibres (SMF 28®) with nine FBGs each. Groups of three sensors were formed in the same section of the cable in such a way that all nine groups are distributed along the cable extension. This distribution allows not only a distributed monitoring of temperature but also a statistical treatment for each section since it provides three individual readings.

The cable was installed near the Vagueira Bridge, at Mira Channel towards Costa Nova, in an extension of approximately $850 \mathrm{~m}$. To guarantee that the sensors were measuring the bottom temperature, a concrete support was used (see fig. 10). The measuring equipment consists of a super luminescent erbium-doped fiber source (FIBERWHITE-SP) to illuminate a FBG sensor, an optical spectrum analyzer (ANDO-Q6330) and an optical fibre switch (JDS Fitel), inter-connected all through a GPIB bus and controlled by a personal computer running LabView software (see fig. 11).

In figure 12 we can see the FBG sensor, the position inside the cable and the attenuation of optical cable sensing using an optical time domain reflectometer (OTDR). A floating raft was used for installing of the optical cable (see fig. 13).

The values of temperature variation for the period between 4 and 23 June, 2002, are presented herein. The water temperature variations in shallow tidal environments, such as this one, are essentially dependent on the tidal dynamics and on surface

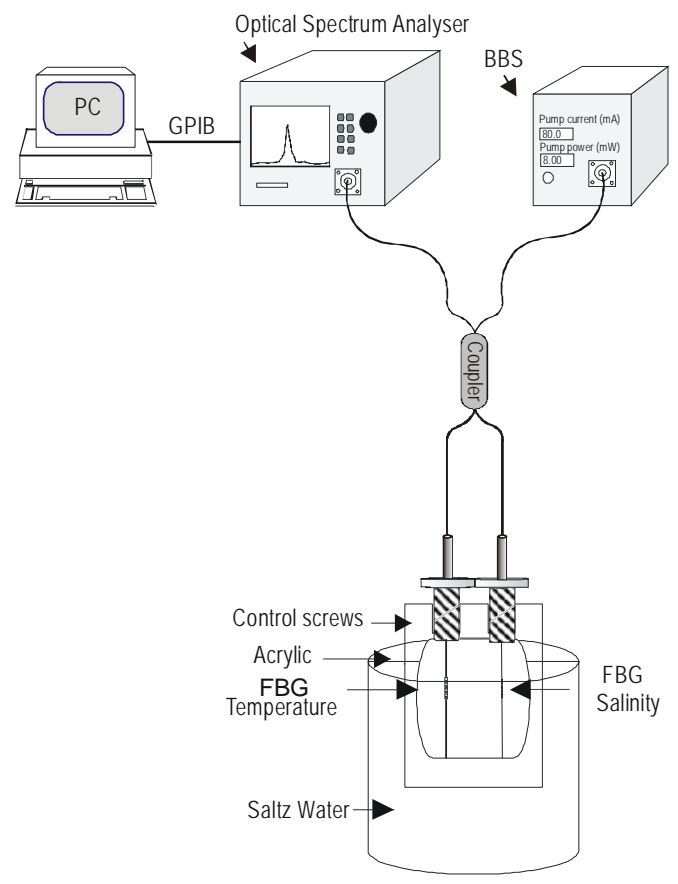

Figure 8. Experimental setup. Figura 8. Arreglo experimental. salinidad (ya mencionado) en el extremo del cable óptico. El monitoreo se realiza mediante un cable de fibra óptica especialmente diseñado (TON GERE), con sensores de rejillas de Bragg, fabricados por CABELTE, S.A.

El cable óptico comprende tres fibras ópticas (SMF 28®) con nueve FBGs cada uno. Se formaron grupos de tres sensores en la misma sección del cable de tal forma que los nueve grupos están distribuidos en toda la extensión del cable. Esta distribución permite tanto un monitoreo distribuido de la temperatura como un tratamiento estadístico en cada sección dado que proporciona tres lecturas individuales.

El cable fue instalado cerca del Puente de Vagueira, en el Canal de Mira, hacia Costa Nova, en una extensión de aproximadamente $850 \mathrm{~m}$. Para garantizar que los sensores estuvieran midiendo la temperatura del fondo, se utilizó una base de concreto (ver fig. 10). El equipo de medición consiste de una fuente de fibra dopada con erbio super luminiscente (FIBERWHITE-SP) para iluminar el sensor de FBG, un analizador de espectro óptico (ANDO-Q6330) y un conmutador de fibra óptica (JDS Fitel), todos interconectados mediante un bus GPIB y controlados por una computadora personal con paquetería de LabView (ver fig. 11).

La figura 12 muestra el sensor de FBG, la posición dentro del cable y la atenuación del cable de fibra óptica utilizando un

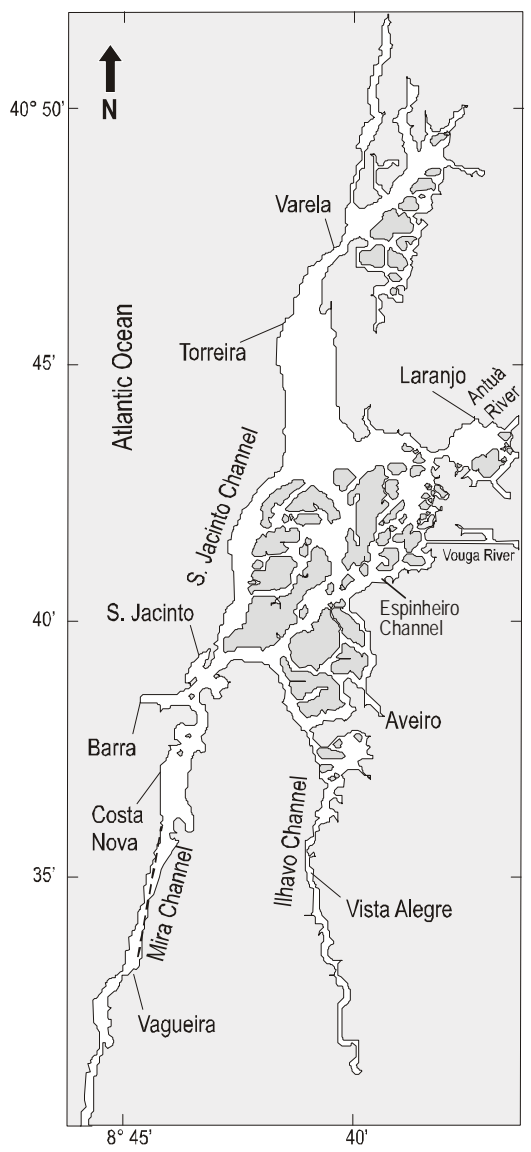

Figure 9. Geographic map of Ría de Aveiro (Portugal). Figura 9. Mapa geográfico de la Ría de Aveiro (Portugal). 


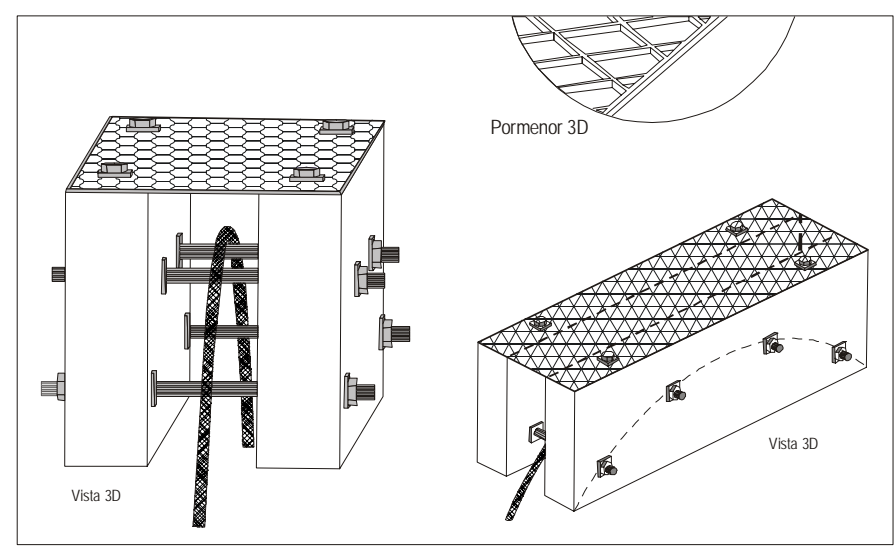

Figure 10. Concrete support of the optical fibre cable. Figura 10. Base de concreto del cable de fibra óptica.

heating. However, temperature variations also occur due to fresh-water inflow. The analysis of figures 14 and 15 reveals that the values measured have periodic evolution, similar to that observed by Dias et al. (1999) using STD observations in nearby locations. The period observed in this variation is about $12 \mathrm{~h} 25 \mathrm{~min}$, which corresponds to the period of the lunar principal $\left(\mathrm{M}_{2}\right)$ constituent of the tide $\left(\mathrm{M}_{2}\right.$ is the main tidal constituent in Ría de Aveiro). The maximum values of the curves are observed at the local low tide, while the minimum values occur at the local high tide. In this season the oceanic water, which propagates through the Mira Channel during the flooding, is cooler than both the fresh water input and the water inside the lagoon. Then the observed temperature pattern is coherent with the tidal dominance of the channel dynamics.

The analysis of figure 14 reveals that the first sensor has a pattern different from the other sensors because, due to the local dynamics, bottom sediments covered that sensor and the

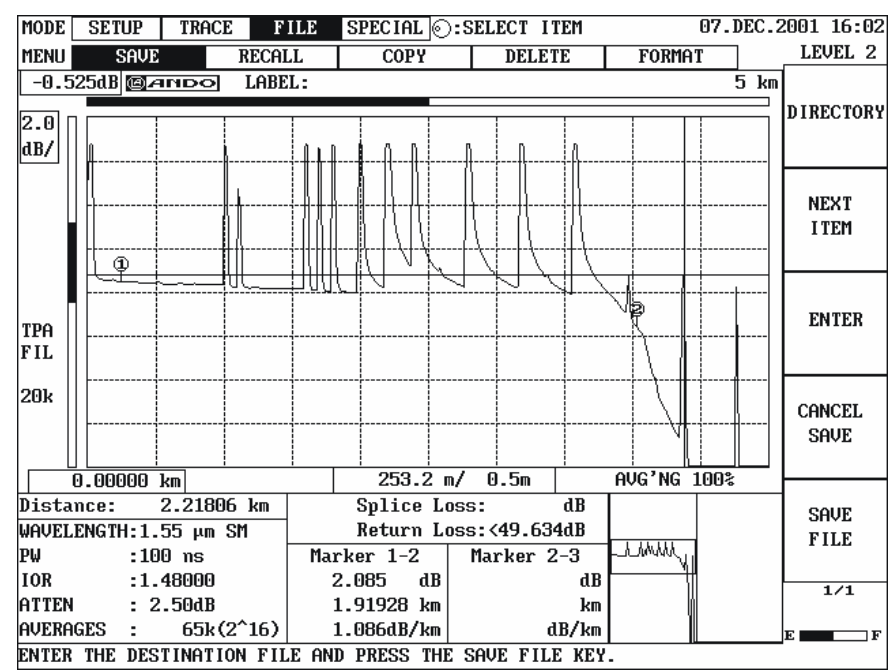

Figure 12. Optical time domain reflectometer (OTDR) spectrum of the fibre Bragg grating sensor.

Figura 12. Espectro del reflectómetro óptico en el dominio del tiempo (OTDR) del sensor de fibra óptica con rejillas de Bragg.

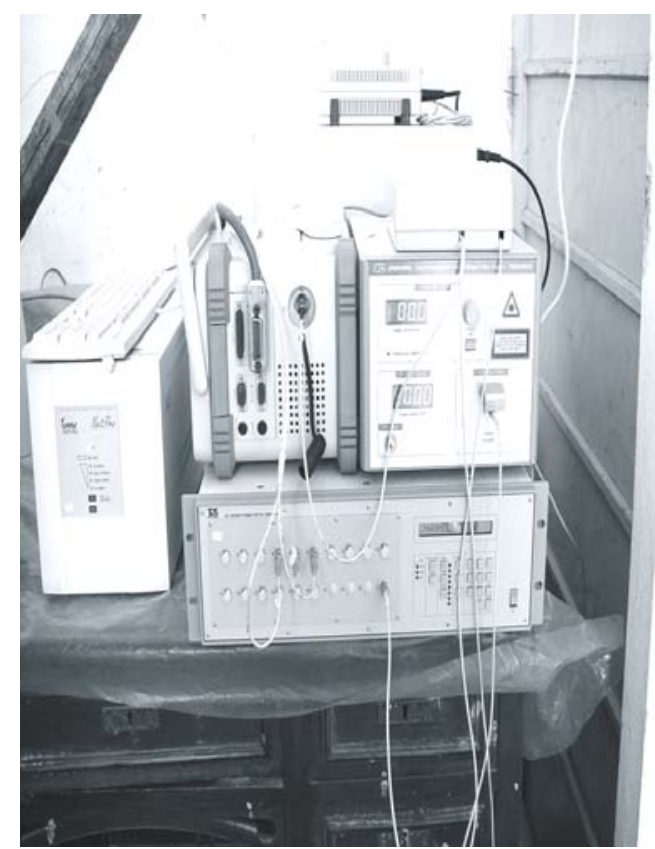

Figure 11. Monitoring equipment.

Figura 11. Equipo de monitoreo.

reflectómetro óptico en el dominio del tiempo (OTDR, por sus siglas en inglés). Para la instalación del cable óptico, se usó una balsa flotante (ver fig. 13).

Aquí se presentan los valores de la variación de temperatura entre el 4 y el 23 de junio de 2002. Las variaciones de la temperatura del agua en ambientes someros con influencia mareal, como en este caso, dependen esencialmente de la dinámica de la marea y del calentamiento superficial. Sin embargo, también hay variaciones de temperatura debidas a la entrada de agua dulce. Las figuras 14 y 15 muestran que los valores medidos tienen una evolución periódica, similar a la observada por Dias et al. (1999) usando observaciones con STD en localidades cercanas. El periodo obsevado de variación es de alrededor de 12 h 25 min, lo que corresponde al periodo del principal $\left(\mathrm{M}_{2}\right)$ componente lunar de la marea $\left(\mathrm{M}_{2}\right.$ es el principal compo-

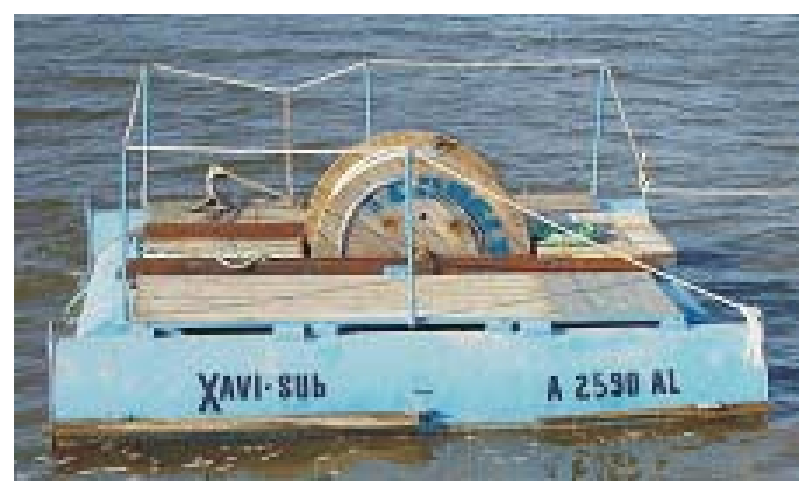

Figure 13. Floating raft used for installing the optical cable.

Figura 13. Balsa flotante usada para la instalación del cable óptico. 


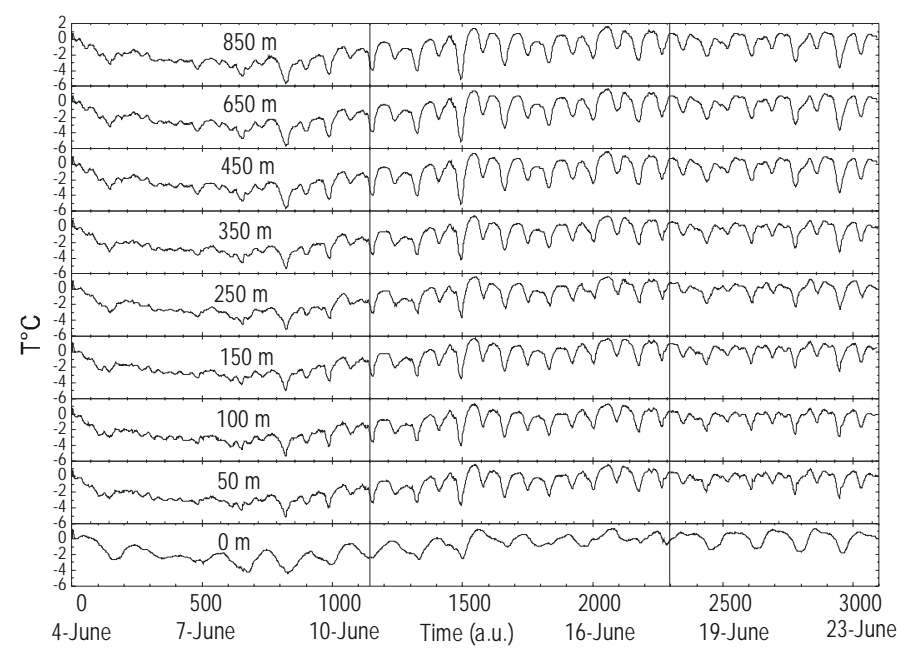

Figure 14. Temperature variation between 4 and 23 June, 2002.

Figura 14. Variación de temperature del 4 al 23 de junio de 2002.

measurements thus correspond to the sediment temperature variation. The temperature variations for the other sensors show different results between the first week and the remaining sampling period. The first week corresponds to a period of neap tides and, therefore, tidal modulation is less effective. During this period there was also occurrence of precipitation and, therefore, the fresh-water inputs at the far end of the channel were more significant. These reasons explain the more irregular temperature pattern observed during the first week. The tidal mean values of the water temperature also increased after the first week, in response to the $30^{\circ} \mathrm{C}$ increase in air temperature and cloudy conditions, and hence, the surface heating.

Figure 15 shows the temperature difference between three points located at different distances from the mouth of the lagoon. During the local low tide the temperature is the same in all the points, but during the local high tide minimum values decrease toward the mouth of the lagoon (there is a difference of about $1^{\circ} \mathrm{C}$ between the $50-\mathrm{m}$ point and the $850-\mathrm{m}$ point). This pattern is explained considering that the $850-\mathrm{m}$ point is closer to the mouth of the lagoon and, therefore, is under a stronger tidal influence. During its propagation along the Mira Channel, the tidal wave amplitude decreases toward the channel head (Dias et al., 2000).

In summary, we have presented two novel technologies based on FBG sensors. The sensing head for the simultaneous measurement of salinity and temperature showed good results and is an interesting alternative to conventional monitoring technology. The sensing cable performed very well and has a good potential for widespread application due to its low size and weight, almost non-intrusive character and its possibile expansion to perform other relevant measurements, including those made with the salinity sensor mentioned above.

\section{Acknowledgements}

This research would not have been possible without the nente mareal en Ría de Aveiro). Los valores máximos de las curvas se observan durante la marea baja local y los mínimos durante la marea alta local. En esta época, el agua oceánica que se propaga por el Canal de Mira durante la subida de la marea es más fría que tanto el agua dulce que entra como el agua dentro de la laguna. Por ende, el patrón de tamperatura observado es coherente con la predominancia de las mareas en la dinámica del canal.

El análisis de la figura 14 revela que el primer sensor tiene un patrón diferente al de los otros sensores ya que, debido a la dinámica local, los sedimentos del fondo cubrieron aquel sensor y, por tanto, sus mediciones corresponden a la variación de temperatura de los sedimentos. Las variaciones de temperatura registradas por los otros sensores muestran resultados diferentes entre la primera semana y el resto del periodo de muestreo. La primera semana corresponde a un periodo de mareas muertas y, por ende, la modulación de las mareas es menos efectiva. Durante este periodo también hubo precipitación y, por lo tanto, los aportes de agua dulce en el extremo lejano del canal fueron más significativos. Estas razones explican el patrón de temperatura más irregular observado durante la primera semana. Los valores medios mareales de la temperatura del agua también se incrementaron después de la primera semana, en respuesta al aumento de $30^{\circ} \mathrm{C}$ en la temperatura del aire y a las condiciones de alta nubosidad y, consecuentemente, al calentamiento superficial.

La figura 15 muestra la diferencia de temperatura entre tres puntos localizados a distintas distancias de la boca de la laguna. Durante la marea baja local la temperatura es igual en todos los puntos, pero durante la marea alta local los valores mínimos decrecen hacia la boca (hay una diferencia de alrededor de $1^{\circ} \mathrm{C}$ entre el punto de $50 \mathrm{~m}$ y el de $850 \mathrm{~m}$ ). Este patrón se explica considerando que el punto de $850 \mathrm{~m}$ está más cerca de la boca de la laguna y, por tanto, bajo una mayor influencia de la marea. Durante su propagación por el Canal de Mira, la

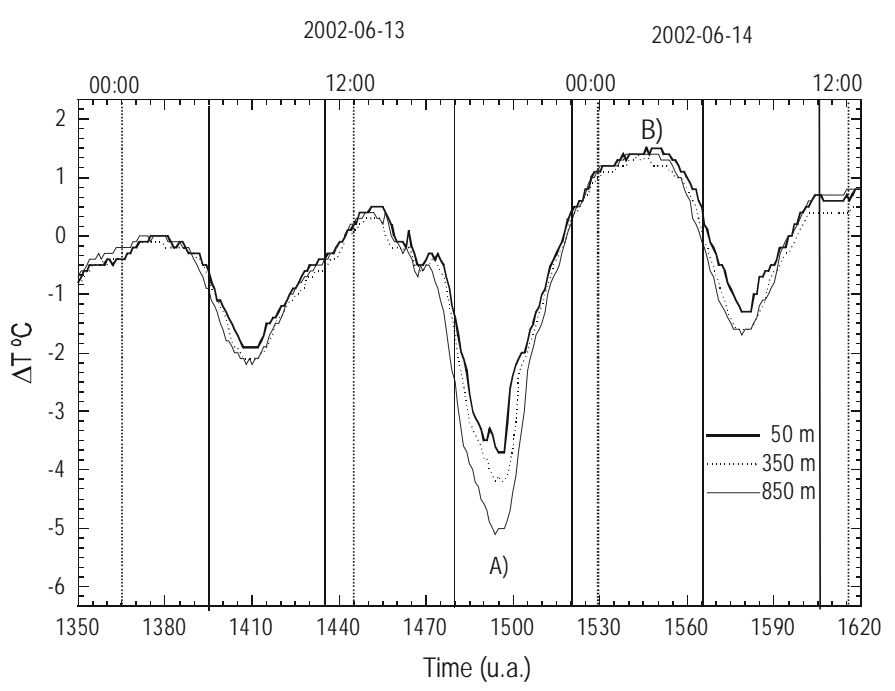

Figure 15. Temperature measurement of 13 June, 2002.

Figura 15. Medición de temperature del 13 de junio de 2002. 
support from Fundação para Ciência e Tecnologia to the PROTEU project. The authors would also like to thank Irmãos Cavaco, S.A.

\section{References}

Asseh, A., Sandgren, S., Ahlfeldt, H., Sahlgren, B., Stubbe, R. and Edwall, G. (1998). Fiber Optical Bragg Grating Refractometer Fiber and Integrated Optics.

Dias, J.M., Lopes, J.F. and Dekeyser, I. (1999). Hydrological characterisation of Ría de Aveiro, Portugal, in early summer. Oceanol. Acta: 22(5): 473-485.

Dias, J.M., Lopes, J.F. and Dekeyser, I. (2000). Tidal propagation in Ría de Aveiro Lagoon, Portugal. Phys. Chem. Earth, 25(4): 369-374.

Esteban, Ó., Navarrete, M.C., Cano, A.G. and Bernabeu, E. (1999). Measurement of the degree of salinity of water with a fiber-optic sensor. Appl.Opt, 38: 5267-5271.

Quan, X. and Fry, E.S. (1995). Empirical equation for the index of refraction of seawater. Appl..Opt., 34: 3477-3480. amplitud de onda mareal decrece hacia la cabeza del canal (Dias et al., 2000).

En conclusión, se han presentado dos tecnologías nuevas basadas en sensores de fibra óptica con rejillas de Bragg. El sensor para la medición simultánea de salinidad y temperatura arrojó buenos resultados y es una alternativa interesante a la teconología convencional. El cable de fibra óptica se desempeñó bien y tiene buen potencial para varias aplicaciones debido a su tamaño pequeño y peso ligero, su carácter no intrusivo y la posibilidad de expanderlo para realizar otras mediciones relevantes como las obtenidas por el sensor de salinidad mencionado en este trabajo.

\section{Agradecimientos}

Esta investigación no hubiera sido posible sin el apoyo de la Fundação para Ciência e Tecnología al proyecto PROTEU. Los autores también agradecen a Irmãos Cavaco, S.A.

Traducido al español por Christine Harris. 